\title{
Interactions between whey proteins and salivary proteins as related to astringency of whey protein beverages at low $\mathrm{pH}$
}

\author{
A. Ye, ${ }^{1}$ C. Streicher, and H. Singh \\ Riddet Institute, Massey University, Private Bag 11 222, Palmerston North 4442, New Zealand
}

\begin{abstract}
Whey protein beverages have been shown to be astringent at low $\mathrm{pH}$. In the present study, the interactions between model whey proteins ( $\beta$-lactoglobulin and lactoferrin) and human saliva in the $\mathrm{pH}$ range from 7 to 2 were investigated using particle size, turbidity, and $\zeta$-potential measurements and sodium dodecyl sulfate-PAGE. The correlation between the sensory results of astringency and the physicochemical data was discussed. Strong interactions between $\beta$-lactoglobulin and salivary proteins led to an increase in the particle size and turbidity of mixtures of both unheated and heated $\beta$-lactoglobulin and human saliva at $\mathrm{pH} \sim 3.4$. However, the large particle size and high turbidity that occurred at $\mathrm{pH} 2.0$ were the result of aggregation of human salivary proteins. The intense astringency in whey protein beverages may result from these increases in particle size and turbidity at these $\mathrm{pH}$ values and from the aggregation and precipitation of human salivary proteins alone at $\mathrm{pH}<3.0$. The involvement of salivary proteins in the interaction is a key factor in the perception of astringency in whey protein beverages. At any $\mathrm{pH}$, the increases in particle size and turbidity were much smaller in mixtures of lactoferrin and saliva, which suggests that aggregation and precipitation may not be the only mechanism linked to the perception of astringency in whey protein.
\end{abstract}

Key words: whey protein beverage, $\beta$-lactoglobulin, lactoferrin, astringency

\section{INTRODUCTION}

Astringency has been recognized as an important component of many beverages such as wine, juices, tea, and, more recently, whey protein beverages at low $\mathrm{pH}$ (Joslyn and Goldstein, 1964; Scharbert et al., 2004; Sano et al., 2005; Bajec and Pickering, 2008; Beecher et al., 2008; Lee and Vickers, 2008). Astringency is described by Lee and Lawless (1991) as a group of

Received May 23, 2011.

Accepted August 16, 2011.

${ }^{1}$ Corresponding author: a.m.ye@massey.ac.nz complex sensations that involve the drying and perceived roughness of oral surfaces with the additional perception of tightening, drawing in, or puckering of the oral mucosa and muscles around the mouth. Understanding the mechanisms behind the perception of astringency is vital to the further development of foods and beverages. Astringency in beverages such as wines and teas is attributed to the polyphenolic compounds that they contain. These polyphenolic compounds interact with salivary proteins, especially proline-rich proteins, to form precipitates on the oral surfaces ( $\mathrm{Jö}_{-}$ bstl et al., 2004). Astringency has been shown to be a tactile sensation, with astringent compounds stripping the oral cavity of the proteins that provide lubrication. The decreased lubrication ability of the proteins causes increased friction in the oral cavity, which stimulates the mechanoreceptors leading to the perception of astringency (Lymann and Green, 1990).

Recently, with increasing demand for protein-fortified beverages, the astringency of whey proteins has been a major concern. It is generally agreed that the astringency of whey protein increases with increasing protein concentration in beverages at $\mathrm{pH} 3.5$ (Sano et al., 2005; Beecher et al., 2008; Vardhanabhuti et al., 2010). However, the exact source of the astringency in whey protein beverages has not been determined. Beecher et al. (2008) suggested that positively charged whey protein molecules at $\mathrm{pH}$ values lower than their isoelectric point (pI) interact with negatively charged salivary proteins to form aggregates, a mechanism that is generally similar to that proposed for polyphenols, which leads to the increase in astringency at $\mathrm{pH}$ 3.5. In another report, it was suggested that the acids used to prepare the beverages cause the astringency (Lee and Vickers, 2008) because acids are known to be astringent (Thomas and Lawless, 1995; Lawless et al., 1996; Sowalsky and Noble, 1998). However, recent research showed that whey proteins may be responsible for the sensation of astringency (Vardhanabhuti et al., 2010), because lactoferrin, which is positively charged at neutral $\mathrm{pH}$, was astringent at $\mathrm{pH} 7$ when no acid was added, suggesting that the interaction between positively charged lactoferrin and negatively charged salivary protein contributed to the astringency. How- 
ever, the charge on the salivary proteins decreased as the $\mathrm{pH}$ decreased from 3.4 to 2.6 , and even became zero at about $\mathrm{pH}$ 3.0, which reduced their interactions with whey proteins, but the astringency of whey protein beverages remained high at $\mathrm{pH}<3.0$ and even at $\mathrm{pH} 2$ (Kelly et al., 2010).

In mixtures of whey proteins and saliva, the turbidity was greatest in the $\mathrm{pH} 4$ to 5 range, indicating that most precipitation of protein under oral conditions occurred at close to the pI of whey proteins (Kelly et al., 2010). It appeared that the most intense astringency and the greatest turbidity did not occur at the same $\mathrm{pH}$, suggesting that precipitation of whey proteins may not be correlated with the astringency of whey protein beverages. Therefore, another mechanism may exist, in addition to charge interactions between whey proteins and salivary proteins leading to precipitation, for the perception of astringency in whey protein beverages.

For these reasons, further studies to understand the interactions between whey proteins and saliva over a wide $\mathrm{pH}$ range and using alternative techniques are required. The objective of this study was to examine the interactions between native or denatured whey proteins ( $\beta-\mathrm{LG}$ and lactoferrin) and human saliva from $\mathrm{pH}$ 2.0 to $\mathrm{pH} 7.0$ through measurements of particle size, turbidity, and $\zeta$-potential. The results were compared with corresponding sensory data for astringency in an attempt to reveal the mechanism for astringency in whey protein beverages at low $\mathrm{pH}$.

\section{MATERIALS AND METHODS}

\section{Materials}

Whey protein isolate (WPI) was kindly provided by Fonterra Co-operative Group Ltd. (Palmerston North, New Zealand) and contained at least $90 \%$ protein. Bovine $\beta$-LG (Sigma Chemical Co., St. Louis, MO) contained approximately 90\% $\beta$-LG. Lactoferrin (Tatua, Morrinsville, New Zealand) contained approximately $90 \%$ lactoferrin. Milli-Q water (water purified by treatment with a Milli-Q apparatus; Millipore Corp., Bedford, MA) was used for the preparation of all solutions. All other chemicals were purchased from Sigma unless otherwise specified.

\section{Preparation of Protein Solutions}

Whey protein isolate $(5.0 \% \mathrm{wt} / \mathrm{wt}), \beta-\mathrm{LG}(2.0 \% \mathrm{wt} /$ $\mathrm{wt})$, and lactoferrin $(2.0 \% \mathrm{wt} / \mathrm{wt})$ were dissolved in Milli-Q water. The solutions were hydrated for $2 \mathrm{~h}$ at room temperature with stirring until fully dissolved. Sucrose (7\% wt/wt) was added to the WPI solutions for the astringency test. The solutions were divided into 2 parts, with 1 part being heated in a shaking water bath at $90^{\circ} \mathrm{C}$ for $15 \mathrm{~min}$ and then cooled to room temperature. All solutions were adjusted to various $\mathrm{pH}$ values using $0.1 M$ and $1 M$ sodium hydroxide and phosphoric acid.

\section{Preparation and Evaluation of Beverages}

Whey proteins were hydrated in water at the concentration required and then allowed to hydrate for 30 min. Sugar and other additives such as polysaccharides were prepared at the required concentration using freshly boiled (i.e., hot) water. Equal quantities of the solutions were mixed and the $\mathrm{pH}$ was adjusted to 3.4 with phosphoric acid. The solutions were then heated to $90^{\circ} \mathrm{C}$ in a hot water bath, held for $10 \mathrm{~min}$, and immediately cooled in ice water.

Black tea was used for the panel screening sessions. First, $3 \mathrm{~L}$ of boiling water was added to 15 tea bags (Dilmah, packed by KJF Group, Peliyaga, Sri Lanka). Two dilutions were made by combining $1.5 \mathrm{~L}$ of tea with $1.5 \mathrm{~L}$ of water and $1.125 \mathrm{~L}$ of tea with $1.875 \mathrm{~L}$ of water. Each panelist was then presented with 3 samples with 2 dilutions the same and 1 different and was asked to select the sample that they considered different. The evaluations were done in individual booths with red lighting to mask the color differences.

The sensory panel was trained using 5\% WPI solutions with $7.5 \%$ sugar with the $\mathrm{pH}$ at near neutral $(\mathrm{pH}$ $6.6), 6.0,5.0,4.5$, and 3.4. In a roundtable situation, the panelists were asked to score for the attributes "sour" and "astringent." This training was carried out 3 times. Panelists appeared able to perceive an increase in sourness and astringency with a decrease in $\mathrm{pH}$.

For the sensory evaluation, the $\mathrm{pH}$ of the solutions was adjusted as required with concentrated phosphoric acid before heating, and the resulting solutions were evaluated by a trained sensory panel consisting of the 12 panelists (age from 20 to $50 \mathrm{yr}$ old, $70 \%$ female and $30 \%$ male) who showed the best performance in the triangle test of all individuals selected for training. In individual booths and under red light to mask the color differences, the panelists were asked to evaluate the samples for astringent and sour intensities using a scale from 0 to 7 . They evaluated 3 replicates of each sample.

\section{Collection of Human Saliva}

Saliva was collected from 5 participants per session for several weeks. All participants had passed a health questionnaire before the study. They were asked not to eat or drink (except water) for $2 \mathrm{~h}$ before the collection 
of saliva. At the time of collection, the participants chewed a sugar- and flavor-free chewing gum (Wrigley's Extra) for 3 min to stimulate the production of saliva by mastication. The aim was to collect clean saliva. They chewed the chewing gum again with 10 $\mathrm{mL}$ of water for $30 \mathrm{~s}$ twice, discarding the water, and retaining the chewing gum in the mouth. In the last step before the collection of saliva, they chewed the chewing gum for $30 \mathrm{~s}$ to stimulate the production of saliva and discarded this stimulated saliva. Saliva was collected over about $15 \mathrm{~min}$ and it was expected that each participant would give about $10 \mathrm{~mL}$ of saliva per session. The saliva samples were stored on chilled ice during collection, centrifuged (Sorvall Evolution RC superspeed centrifuge, Thermo Scientific, Asheville, $\mathrm{NC})$ at $4^{\circ} \mathrm{C}$ at $10,000 \times g$ for $30 \mathrm{~min}$, pooled, and then stored in a $-80^{\circ} \mathrm{C}$ freezer (Forma 900 series, Thermo Scientific, Marietta, OH) until required.

\section{Preparation of Protein-Saliva Mixtures}

Saliva was mixed with each protein solution in the same ratio (wt/wt), and the mixtures were vortexed and stored at $4^{\circ} \mathrm{C}$ for $24 \mathrm{~h}$ before being evaluated. It was estimated that the mixtures of $\beta$-LG or lactoferrin and saliva would have a protein content of about $1 \%$. The mixtures were adjusted to various $\mathrm{pH}$ values using $0.1 M$ and $1 M \mathrm{NaOH}$ and $0.1 M$ and $1 M$ phosphoric acid.

\section{Measurement of Hydrodynamic Diameter}

The mean hydrodynamic diameters of all samples were measured by a dynamic light scattering technique. The Zetasizer Nano ZS (Malvern Instruments Ltd., Malvern, Worcestershire, UK) uses a $4 \mathrm{~mW}$ helium-neon laser at a wavelength of $633 \mathrm{~nm}$. The size measurements were performed at $25^{\circ} \mathrm{C}$ in a particle-sizing cell using backscattering technology at a detection angle of $173^{\circ}$. The intensity of light scattered from the particles was used to calculate the hydrodynamic diameter. The amount of sample in the cell was about $10 \mu \mathrm{L}$ and each sample was measured 4 times.

\section{Measurement of $\zeta$-Potential}

Samples were diluted 100 times with Milli-Q water. The $\zeta$-potentials of all samples at their particular $\mathrm{pH}$ were measured by laser Doppler velocimetry using the Malvern Zetasizer Nano (Malvern Instruments Ltd.). A 1.0-mL aliquot of each sample was placed in the folded capillary cell and was measured 4 times at $25^{\circ} \mathrm{C}$.

\section{Measurement of Turbidity}

The turbidity of each sample was measured twice using a spectrophotometer (Genesys 10 series, Thermo Electron Scientific Corporation, Madison, WI) operating at a wavelength of $400 \mathrm{~nm}$.

\section{Electrophoresis Analysis (SDS-PAGE)}

The protein composition in the sample mixtures was determined using an SDS-PAGE technique. All samples were centrifuged in a MiniSpin Plus centrifuge (Eppendorf, Hamburg, Germany) at 12,500 $\times g$ for 15 min. The supernatant and the sediment were collected and the sediments were freeze-dried. Freeze-dried aliquots of all sample mixtures were weighed for analysis. Fresh saliva was used as a control.

Sample buffer $(0.5 M$ Tris- $\mathrm{HCl}, \mathrm{pH} 6.8,2.0 \%$ SDS, $5.0 \% \beta$-mercaptoethanol, $10 \%$ glycerol, and $1.0 \%$ bromophenol blue) was mixed with sample in a 1:10 ratio. This sample was heated in a shaking water bath at $95^{\circ} \mathrm{C}$ for $5 \mathrm{~min}$ and then cooled to room temperature. The SDS gel was prepared in a Mini-Protean II system (Bio-Rad Laboratories, Richmond, CA).

The resolving gel contained $16 \%$ acrylamide and 1.5 $M$ Tris- $\mathrm{HCl}$ buffer, $\mathrm{pH}$ 8.8, 10\% SDS, and Milli-Q water. The solution was then degassed for about 15 min, 10\% ammonium persulfate (APS) and $N, N, N^{\prime}, N^{\prime}-$ tetramethylethylenediamine (TEMED) were immediately added, and the solution was gently swirled. The contents were poured between 2 electrophoresis casting plates (0.075 mm gap; Bio-Rad Laboratories). A few drops of water were added on top of the solution, forming an upper layer and preventing the acrylamide solution from drying. The solution was allowed to polymerize at room temperature for about 45 to $60 \mathrm{~min}$ and the water was removed using filter paper before the stacking gel was poured on top. The stacking gel contained $4 \%$ acrylamide, $0.5 M$ Tris- $\mathrm{HCl}$ buffer, $\mathrm{pH} 6.8$, and Milli-Q water, and was degassed for 15 min before $10 \%$ APS and TEMED were added, and, after a gentle swirl, the mixture was poured on top of the resolving gel. A plastic comb (Bio-Rad Laboratories) was placed in the liquid stacking gel solution between the 2 glass plates to provide slots for the samples. The stacking gel was allowed to polymerize at room temperature for 45 to $60 \mathrm{~min}$. The prepared gel was either used immediately or stored at $4^{\circ} \mathrm{C}$ in a moistened, airtight plastic bag for up to $3 \mathrm{wk}$. The Mini-Protean II system was connected to the electricity source via a power supply (PowerPac Basic, Bio-Rad Laboratories) at $200 \mathrm{~V}$ for approximately 60 min until the tracking dye moved out of the gel. The gel was stained in a solution of $0.3 \%$ 
(wt/vol) Coomassie Blue R0250, 10\% (vol/vol) glacial acetic acid, and $20 \%$ (vol/vol) isopropanol.

\section{Statistical Analysis}

The samples were prepared in duplicate, and all tests were replicated twice. The experimental data were evaluated by running ANOVA tests, which determined whether any significant differences were present among the means at a $95.0 \%$ confidence level. These analyses were performed using Minitab 14 for Windows package (Minitab Pty Ltd., State College, PA). Treatment means were considered significantly different at $P \leq$ 0.05 .

\section{RESULTS}

\section{Astringency of WPI Beverage}

The astringency of whey proteins was reported to increase with an increase in protein concentration up to $4 \%$ (wt/wt), but no further change was observed in apparent astringency at protein concentrations from 4 to $13 \%$ (wt/wt) at pH 3.5 (Kelly et al., 2010). Positively charged whey protein molecules at $\mathrm{pH}$ lower than their pI interact with negatively charged salivary proteins, causing precipitation, which leads to intense astringency at pH 3.5 (Beecher et al., 2008; Vardhanabhuti et al., 2010). If charge interactions play an important role in the perception of astringency, the $\mathrm{pH}$ of a solution will be a key factor. Figure 1 shows the astringency of a heated 5\% WPI solution containing $7.5 \%$ sucrose at different $\mathrm{pH}$ values. As expected, little or no perception of astringency was recorded at neutral $\mathrm{pH}$, the

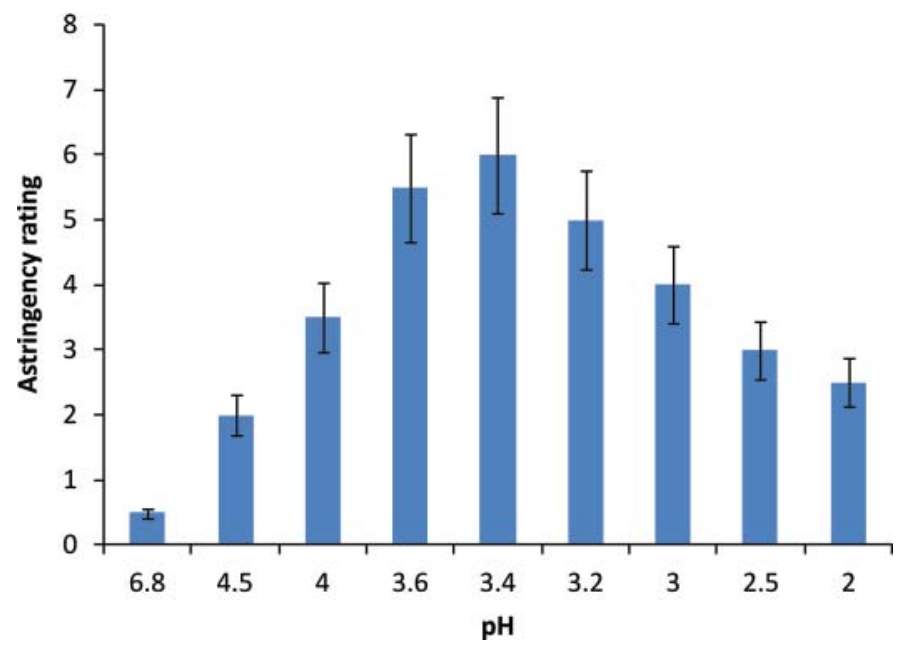

Figure 1. Astringency rating of $5 \%$ (wt/wt) whey protein isolate (WPI) beverage with $7 \%$ (wt/wt) sucrose at different $\mathrm{pH}$ values. The beverage was heated at $90^{\circ} \mathrm{C}$ for $10 \mathrm{~min}$. Color version available in the online PDF. astringency had a rating of $\sim 2$ at $\mathrm{pH} 4.5$, was most intense at around $\mathrm{pH} 3.4$, and then decreased with a further decrease in the $\mathrm{pH}$, but remained high (rating $\sim 3)$ at $\mathrm{pH}$ 2.0. This result was in agreement with the same trend observed by Beecher et al. (2008) of astringency increasing to $\mathrm{pH} \sim 3.4$ and then decreasing. The astringencies of unheated and heated WPI solutions were similar (data not shown), suggesting that heat treatment did not influence the perception of the astringency of whey proteins.

\section{Interactions Between $\beta-L G$ and Human Saliva}

Turbidity. Mixtures of human saliva and unheated or heated $2 \%$ (wt/wt) $\beta$-LG (saliva:protein solution $=$ 1:1) were adjusted to various $\mathrm{pH}$ values. The turbidities
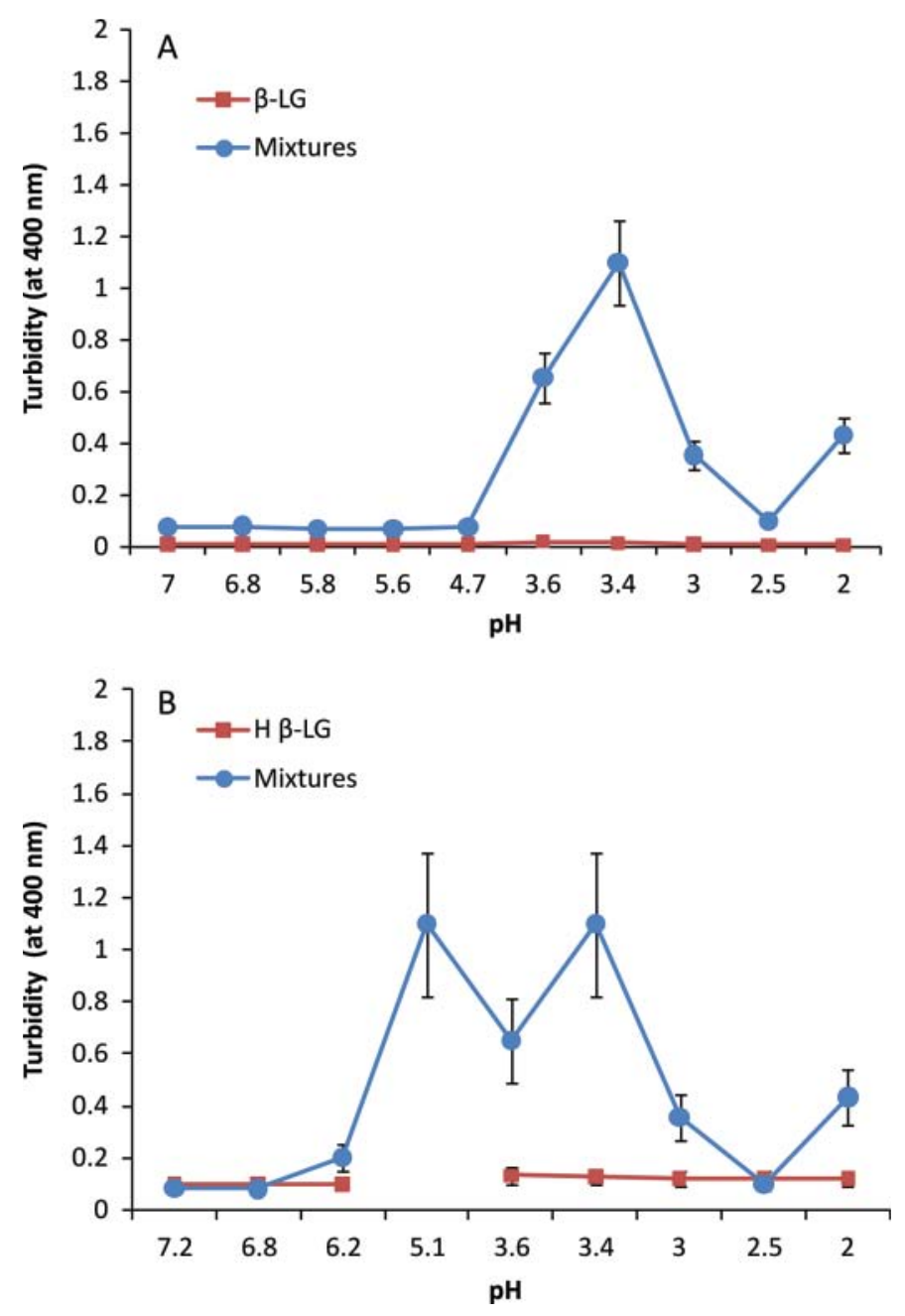

Figure 2. Turbidity of mixtures of $1 \%$ (wt/wt) unheated $\beta$-LG (A) or heated (H) $\beta$-LG (B) and human saliva in a 1:1 ratio as a function of $\mathrm{pH}$ : squares $=\beta-\mathrm{LG}$ solution; circles $=$ mixture of $\beta-\mathrm{LG}$ and saliva. No data points exist for heated $\beta$-LG solution alone between $\mathrm{pH} 6.2$ and 3.6 because of precipitation. Color version available in the online PDF. 

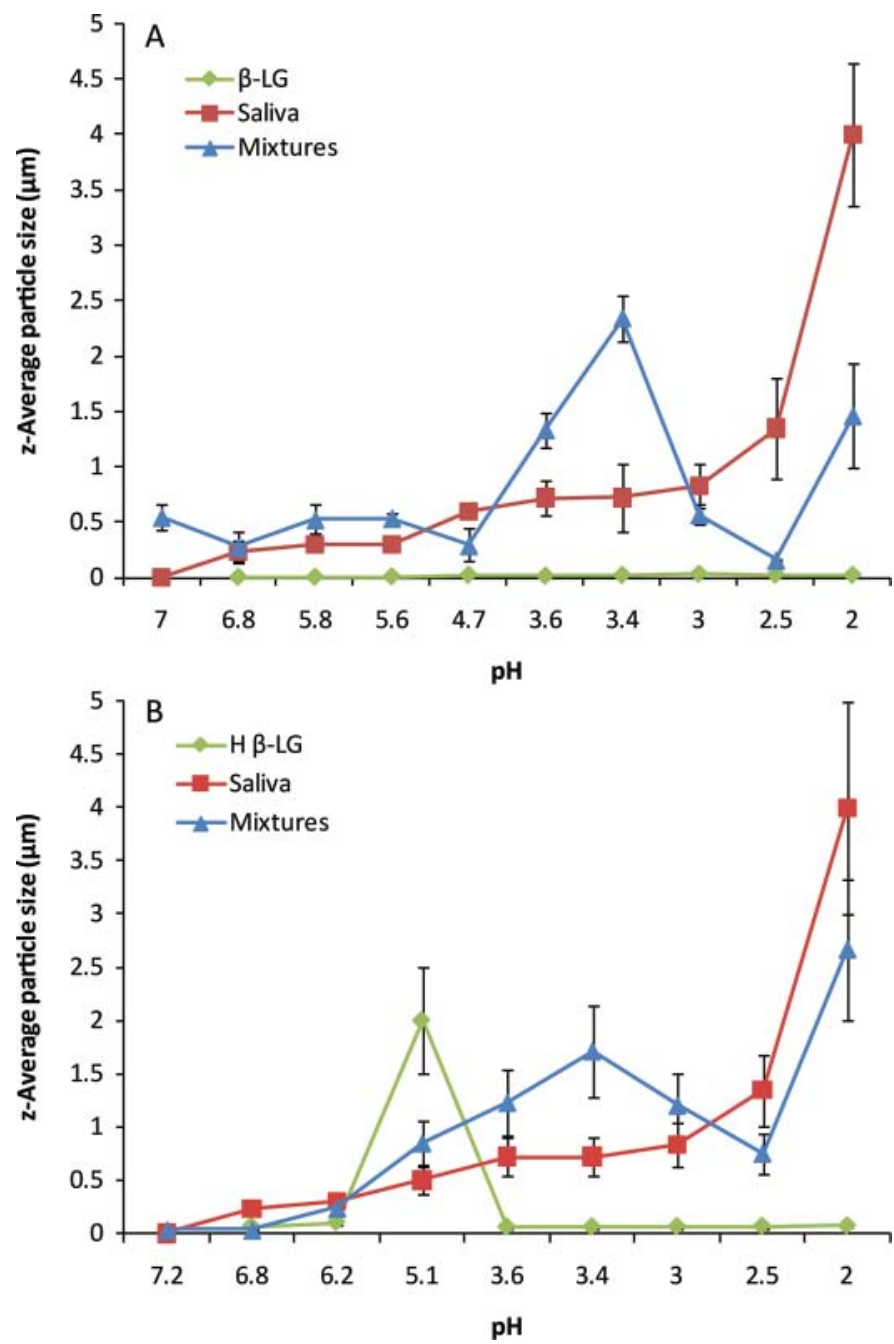

Figure 3. Average particle size of mixtures of unheated $\beta-L G(A)$ or heated (H) $\beta-L G(B)$ and human saliva in a 1:1 ratio as a function of $\mathrm{pH}$ : diamonds $=\beta-\mathrm{LG}$ solution; squares $=$ human saliva; triangles $=$ mixture of $\beta$-LG and saliva. Color version available in the online PDF.

of $\beta$-LG, human saliva, and their mixtures were determined at these $\mathrm{pH}$ values (Figure 2). For the mixture of unheated $\beta$-LG and saliva, turbidity increased as the $\mathrm{pH}$ was decreased below $\mathrm{pH} 4.7$, was greatest at $\mathrm{pH} 3.4$, and then decreased as the $\mathrm{pH}$ was decreased further to $\mathrm{pH}$ 2.5. However, in the mixture of heated $\beta-\mathrm{LG}$ and saliva, 2 peaks were observed, with the turbidity being high at around $\mathrm{pH} 5$ and $\mathrm{pH} 3.4$ (Figure 2B) and low at $\mathrm{pH}$ 2.5. It is noteworthy that turbidity increased again at $\mathrm{pH} 2$ in mixtures of both unheated and heated $\beta-\mathrm{LG}$ and saliva.

Particle Size. Human saliva displayed a moderate particle size (from $\sim 100$ to $\sim 500 \mathrm{~nm}$; Figure 3), which increased gradually when the $\mathrm{pH}$ was decreased from 7 to 3 and increased markedly (to $>2,000 \mathrm{~nm}$ ) at $\mathrm{pH}$ $<2.5$.
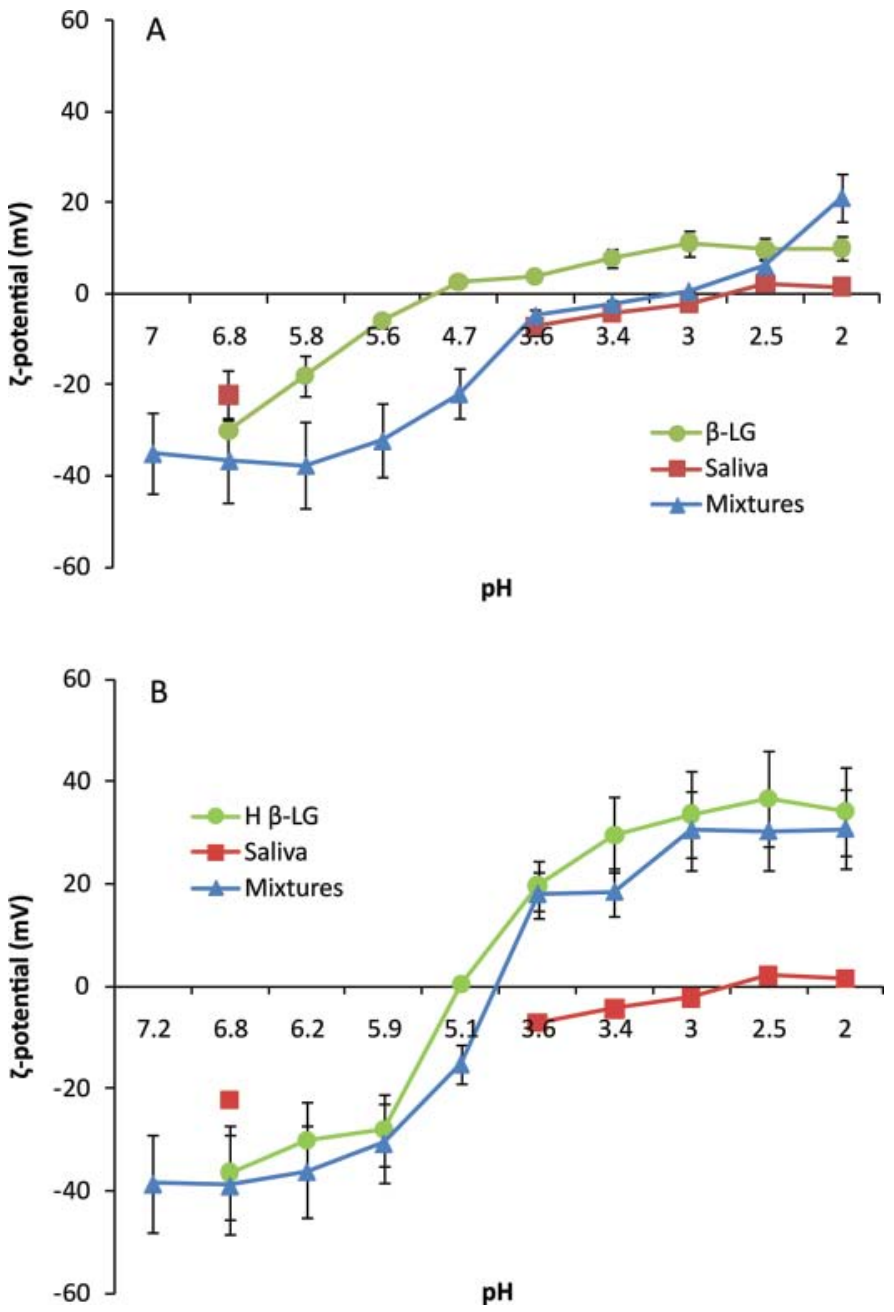

Figure 4. $\zeta$-Potential of mixtures of unheated $\beta$-LG (A) or heated $(\mathrm{H}) \beta-\mathrm{LG}(\mathrm{B})$ and human saliva in a 1:1 ratio as a function of $\mathrm{pH}$ : circles $=\beta-\mathrm{LG}$ solution; squares $=$ human saliva; triangles $=$ mixture of $\beta-\mathrm{LG}$ and saliva. Color version available in the online PDF.

The particle size of a mixture of unheated $\beta-L G$ and saliva was similar to that of saliva in the range from $\mathrm{pH}$ 7 to 4.7 (Figure 3), was higher at $\mathrm{pH} 3.6$ and $\mathrm{pH} 3.4$, and was lower at $\mathrm{pH} 2.0$ and $\mathrm{pH} 2.5$. The trend of the changes in the particle size of a mixture of $\beta-L G$ and saliva with $\mathrm{pH}$ was consistent with the change in the turbidity with $\mathrm{pH}$.

The heated $\beta$-LG solution displayed a large particle size at $\mathrm{pH} 5.1$ because $\beta$-LG aggregated at its pI. Similar to the mixture of unheated $\beta$-LG and saliva, for the mixture of heated $\beta-\mathrm{LG}$ and saliva, the particle size was high between $\mathrm{pH} 3.0$ and $\mathrm{pH} 3.6$, was very high at $\mathrm{pH}$ 2.0 , but was relatively low at $\mathrm{pH} 2.5$.

$\zeta$-Potential. Electrostatic interactions may play an important role in the perception of astringency (Vardhanabhuti et al., 2010), being of particular significance in precipitate formation. $\zeta$-Potential determinations 
may prove to be valuable in obtaining information about possible electrostatic interactions between human saliva and protein compounds.

Figure 4 shows the $\zeta$-potentials of $\beta$-LG, human saliva, and the mixture of $\beta-\mathrm{LG}$ and saliva at different $\mathrm{pH}$ values. The $\zeta$-potential of human saliva was about $-20 \mathrm{mV}$ at $\mathrm{pH} 6.8$, was negative at $\mathrm{pH}>2.5$, and became slightly positive at $\mathrm{pH}<2.5$. However, the $\zeta$-potential was very low at about $\mathrm{pH} 2.5(<10 \mathrm{mV})$. These results were in agreement with previous reports on the $\zeta$-potential of human saliva (Rykke et al., 1996), which demonstrated that the pI of salivary micelle-like particles was about $\mathrm{pH} 3$.

For $\beta$-LG solution, the $\zeta$-potential went from positive to negative at around $\mathrm{pH}$ 5. For the mixture of unheated $\beta$-LG and saliva, the $\zeta$-potential was negative at $\mathrm{pH}>3$ (Figure $4 \mathrm{~A}$ ) and positive at $\mathrm{pH}<3$. For the mixture of heated $\beta$-LG and saliva, the $\zeta$-potential became positive at about $\mathrm{pH} 4$ and increased to a higher level between pH 3.6 and pH 2.0 (Figure 4B).

$\boldsymbol{S} \boldsymbol{D} \boldsymbol{S}-\boldsymbol{P} \boldsymbol{A} \boldsymbol{G E}$. Analysis by SDS-PAGE of the sediments of the mixtures of heated $\beta-\mathrm{LG}$ and saliva after centrifugation are shown in Figure 5. Between pH 3.6 and 3.0, the pellets contained mainly $\beta-\mathrm{LG}$ with very faint bands indicating salivary proteins. However, at
pH 2.5 and $\mathrm{pH} 2.0$, the intensity of the $\beta$-LG band decreased, whereas the intensities of salivary protein (glycosylated proline-rich protein and $\alpha$-amylase) bands increased. Interestingly, at $\mathrm{pH} 2.0$, the sediment appeared to contain mainly salivary proteins, particularly $\alpha$-amylase, with very little $\beta-L G$.

\section{Interactions Between Lactoferrin and Human Saliva}

Lactoferrin has a positive charge at $\mathrm{pH}<8$. The $\zeta$-potential became more positive with decreasing $\mathrm{pH}$ and reached a plateau at $\mathrm{pH}<3.4$ (Figure 6 ). We expected that a charge interaction would occur between lactoferrin and human saliva, which has an overall negative charge at $\mathrm{pH}>3$. The $\zeta$-potential of the mixture of lactoferrin and human saliva displayed positive values in the $\mathrm{pH}$ range from 7 to 2 , following a trend very similar to that of lactoferrin alone.

The average particle size of lactoferrin solution $(2 \%$; either unheated or heated) mixed with human saliva in a 1:1 ratio at different $\mathrm{pH}$ values is shown in Figure 7. In general, the particle size was small in the range from $\mathrm{pH} 8.3$ to 3 compared with that of mixtures of $\beta-\mathrm{LG}$ and saliva (Figure 3 ). The particle size increased at $\mathrm{pH}$ 2 in both the unheated and heated mixtures.

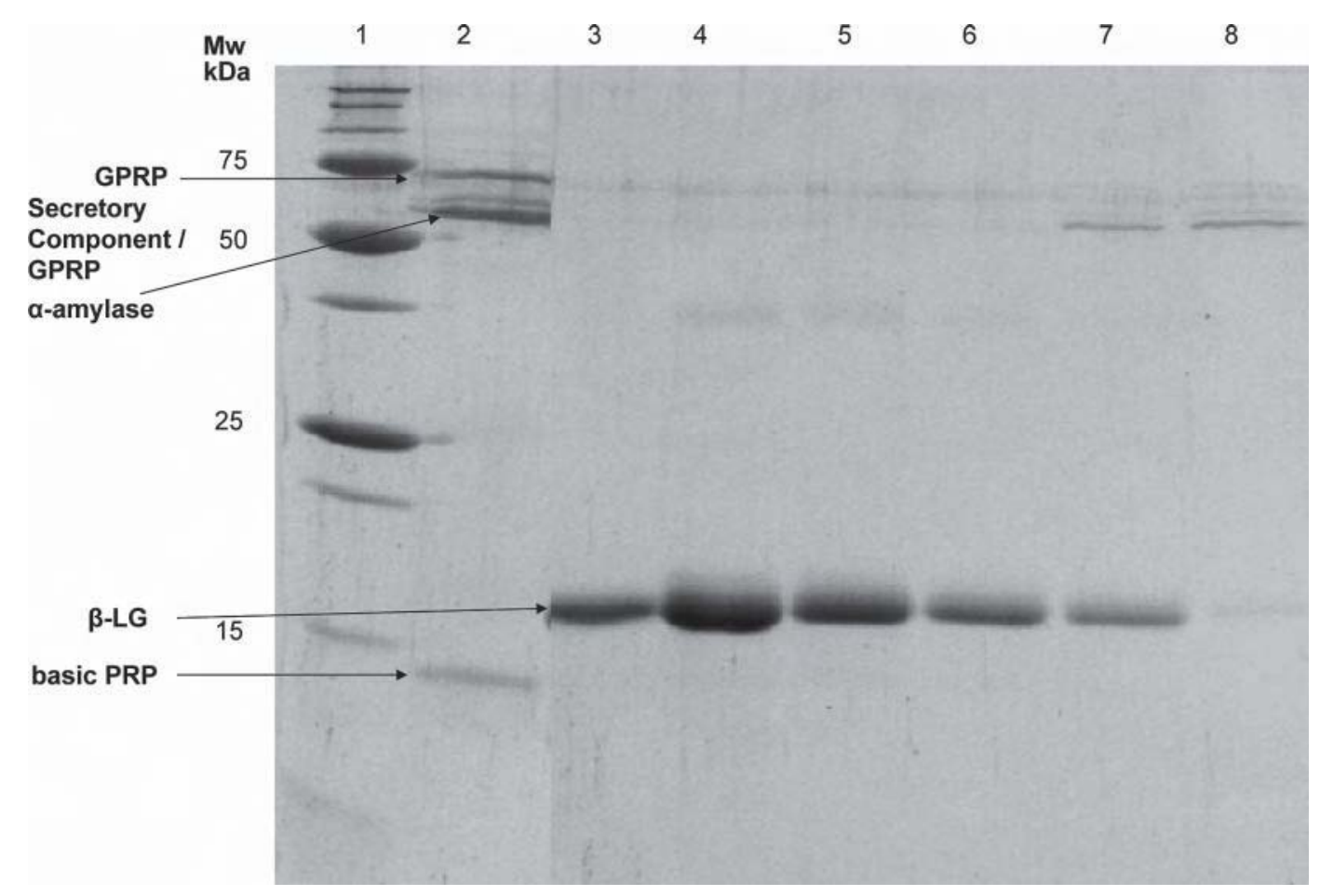

Figure 5. Sodium dodecyl sulfate-PAGE of the sediments from mixtures of heated $\beta$-LG and human saliva in a 1:1 ratio (wt/wt) at different $\mathrm{pH}$ values. Lane $1=$ marker; lane $2=$ human saliva at neutral $\mathrm{pH}$; lane $3=0.1 \%$ heated $\beta$-LG solution (control); lane $4=$ mixture of heated $\beta$-LG and saliva at $\mathrm{pH} 3.6$; lane $5=$ mixture of heated $\beta-\mathrm{LG}$ and saliva at $\mathrm{pH} 3.4$; lane $6=$ mixture of heated $\beta$-LG and saliva at $\mathrm{pH} 3.0$; lane $7=$ mixture of heated $\beta-\mathrm{LG}$ and saliva at $\mathrm{pH} 2.5$; lane $8=$ mixture of heated $\beta$-LG and saliva at $\mathrm{pH} 2.0$. PRP $=$ proline-rich protein; GPRP $=$ glycosylated proline-rich protein. Color version available in the online PDF. 


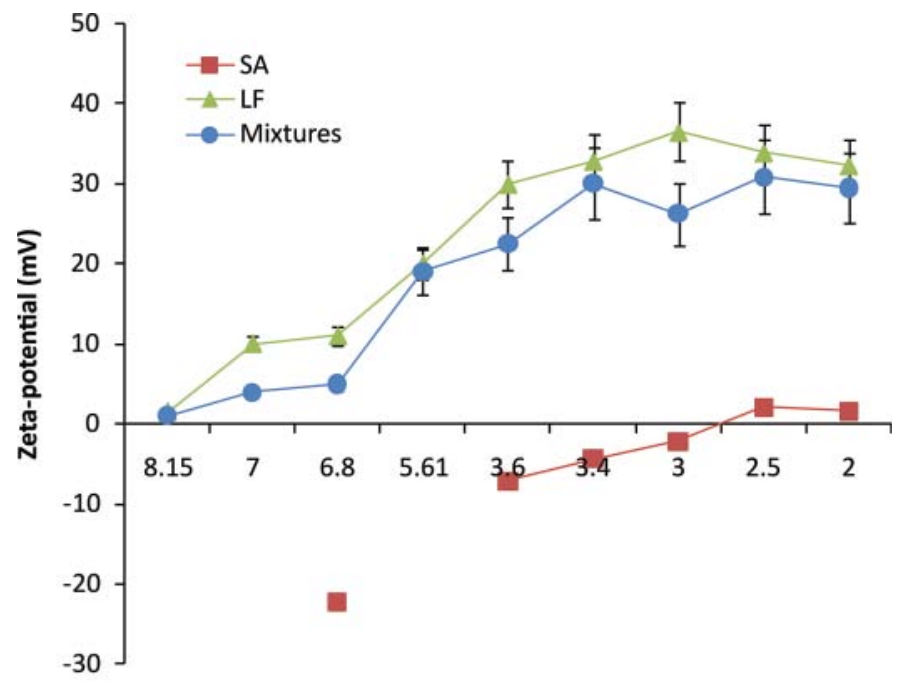

pH

Figure 6. $\zeta$-Potential of mixtures of lactoferrin and human saliva in a 1:1 ratio as a function of $\mathrm{pH}$ : lactoferrin solution (triangles), human saliva (squares), or a mixture of lactoferrin and saliva (circles). Color version available in the online PDF.

After centrifugation, SDS-PAGE showed that the sediment of mixtures of heated lactoferrin and saliva contained mainly lactoferrin at $\mathrm{pH} 6.8$ and $\mathrm{pH} 3.6$, with faint bands of salivary proteins, whereas it contained only salivary protein ( $\alpha$-amylase) at $\mathrm{pH} 2.0$ (Figure 8 ). This result was consistent with the results observed in the mixtures of $\beta$-LG and saliva (Figure 5).

\section{DISCUSSION}

A peak was observed at $\mathrm{pH} 3.4$ in both the turbidity profile and the particle size profile in a $\mathrm{pH}$ range from 2.5 to 4.7 for both the unheated and the heated $\beta$-LG and saliva mixtures. In this $\mathrm{pH}$ range, because $\beta$-LG and human saliva have opposite charges, the increases in turbidity and particle size may be attributed to complexation between $\beta$-LG and salivary components through electrostatic interactions. At $\mathrm{pH} \sim 2.5$, the low turbidity and small particle size may suggest that no interaction occurred because saliva had very low charge $(\zeta$-potential close to zero). It is not clear why the turbidity and the particle size increased again at $\mathrm{pH} 2.0$, but it is likely to follow the high turbidity and the large particle size observed for saliva alone. It appears that $\beta$-LG was not involved in the formation of large particles and the high turbidity at $\mathrm{pH} 2.0$ and that the large particles were created by the aggregation of salivary proteins at this $\mathrm{pH}$. Human saliva contains several spherical or micelle-like particles in the range from 100 to $200 \mathrm{~nm}$, as previously demonstrated by transmission electron microscopy (Rykke et al., 1995). Because hu-
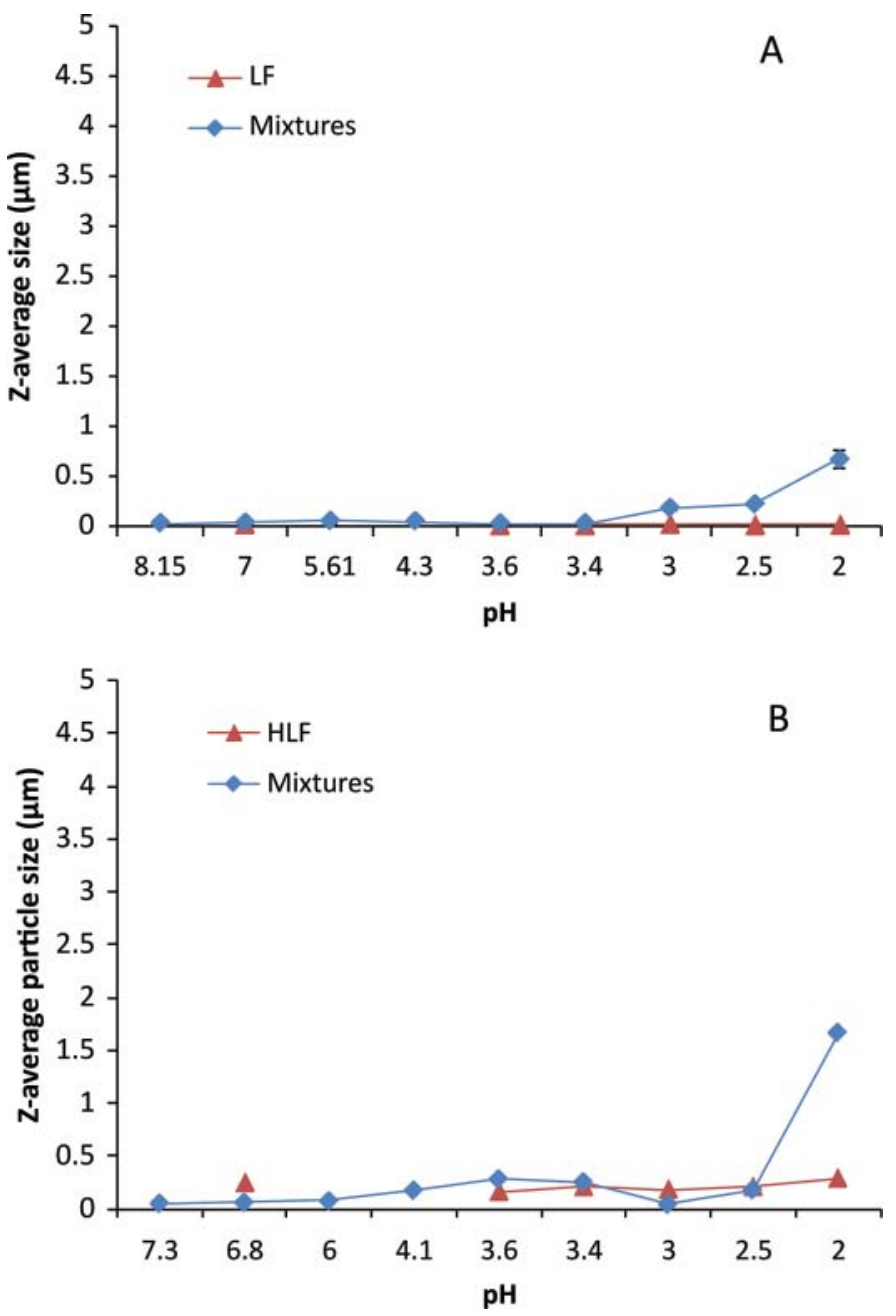

Figure 7. Average particle size of mixtures of unheated lactoferrin (A) or heated lactoferrin (B) and human saliva in a 1:1 ratio as a function of $\mathrm{pH}$ : lactoferrin solution (triangles) or a mixture of lactoferrin and saliva (diamonds). Color version available in the online PDF.

man saliva particles are negatively charged at neutral $\mathrm{pH}$ and have zero charge at about $\mathrm{pH} 3.0$ (Rykke et al., 1996), particle size may change with a change in $\mathrm{pH}$. The large size of saliva particles at low $\mathrm{pH}(\mathrm{pH} 2.5$ and $\mathrm{pH} 2.0$ ) was probably due to aggregation of the saliva particles because of a low overall charge. Sodium dodecyl sulfate-PAGE results supported this suggestion, because the sediment contained mainly salivary proteins and little or no $\beta$-LG at pH 2.0 (Figure 5).

No change in the turbidity and particle size of unheated samples at $\mathrm{pH}>5.0$ suggests no complexation between $\beta$-LG and human saliva, because both $\beta$-LG and the salivary proteins were negatively charged. However, for heated samples, high turbidity and large particle sizes were observed at around $\mathrm{pH} 5$, which could be attributed to aggregation of denatured $\beta-\mathrm{LG}$ at its pI. Therefore, the extra aggregation of whey proteins at 


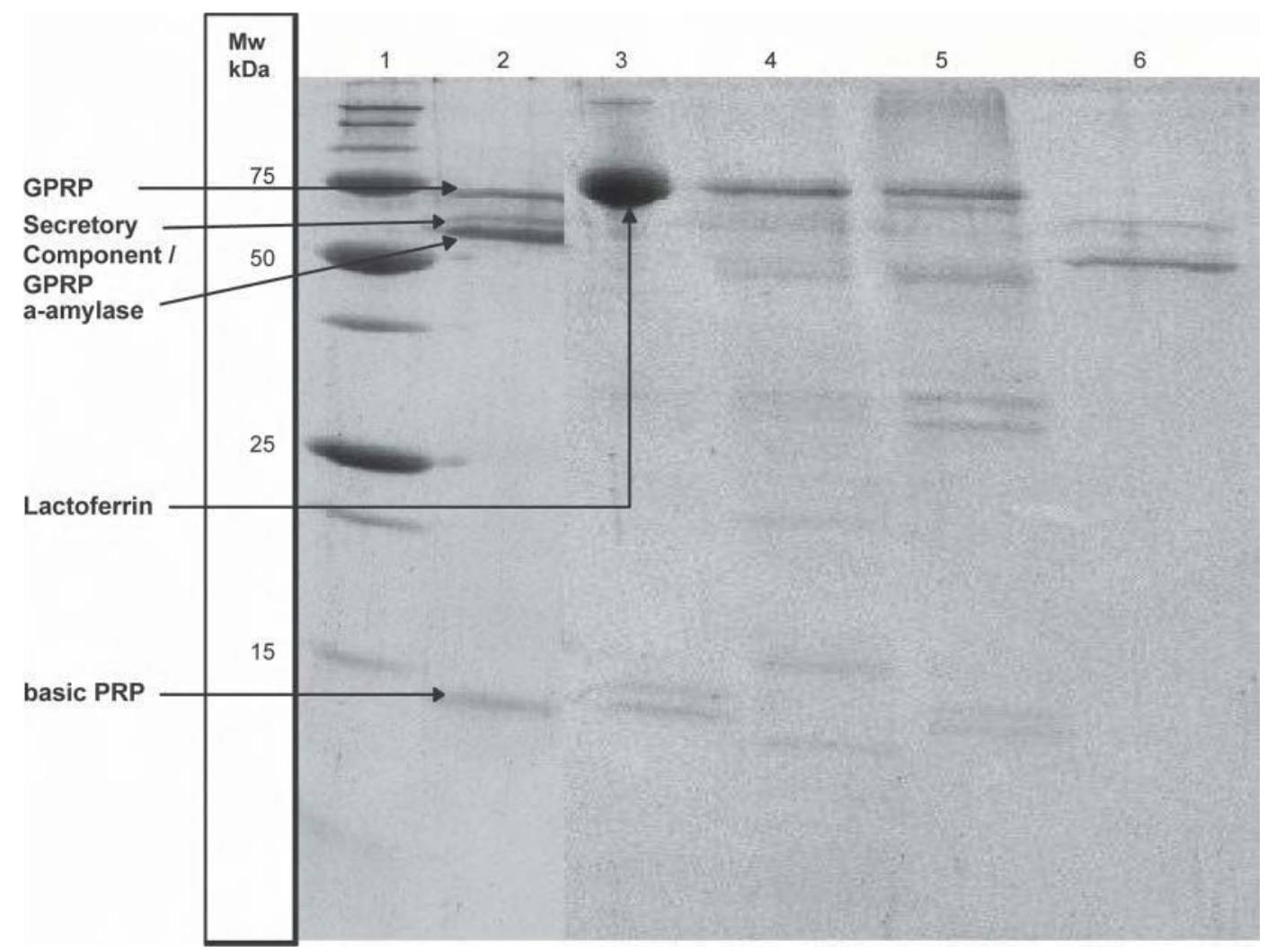

Figure 8. Sodium dodecyl sulfate-PAGE of the sediments from mixtures of heated lactoferrin and human saliva in a 1:1 ratio (wt/wt) at different $\mathrm{pH}$ values. Lane $1=$ marker; lane $2=$ human saliva at neutral $\mathrm{pH}$; lane $3=0.1 \%$ lactoferrin solution (control); lane $4=$ mixture of heated lactoferrin and saliva at $\mathrm{pH} 6.8$; lane $5=$ mixture of heated lactoferrin and saliva at $\mathrm{pH} 3.6$; lane $6=$ mixture of heated lactoferrin and saliva at $\mathrm{pH}$ 2.0. $\mathrm{PRP}=$ proline-rich protein; GPRP $=$ glycosylated proline-rich protein. Color version available in the online PDF.

$\mathrm{pH} 6.1$ to $\sim 4.0$ in the heated samples would not appear to be related to astringency, because no difference was found in the astringency of heated and unheated WPI solutions.

In terms of the relationship between astringency and particle size, marked astringency in the $\mathrm{pH}$ range from 3.0 to 3.6 was consistent with large particle size and high turbidity, suggesting strong interactions between whey proteins and saliva. This is in agreement with Vardhanabhuti et al. (2010), who proposed that charge interactions between whey proteins and salivary proteins play an important role in the astringency of a whey protein solution at $\mathrm{pH} \sim 3.5$. However, no interaction was found between whey proteins and salivary proteins at $\mathrm{pH} 2.0$ because both were positively charged; the astringency, although lower, could probably be attributed to the precipitation of salivary proteins at low $\mathrm{pH}$. Lee and Vickers (2008) considered that the astringency in protein solutions comes from added acid and is not related to the presence of whey protein at low $\mathrm{pH}$. Lee and Vickers (2008) observed the same astringency rating for solutions containing protein and those with no protein with the same amount of added acid. In fact, their 2 samples had different $\mathrm{pHs}$, with the samples containing protein at $\mathrm{pH} 3.4$ and the samples containing no protein at $\mathrm{pH}$ 1.8. In contrast, Vardhanabhuti et al. (2010) suggested that the astringency of whey protein was independent of the amount of added acid. The astringency of a whey protein solution at very low $\mathrm{pH}(\mathrm{pH} 2)$, which required more added acid, was lower than that of a whey protein solution at around $\mathrm{pH}$ 3.4 , indicating that more added acid would not result in higher astringency. However, our results show that the astringency at $\mathrm{pH} 2$ appeared not to result from charge interactions between whey proteins and salivary proteins because both proteins had an overall positive charge.

From this discussion, we suggest that astringency is related to the aggregation and precipitation of matter in the mouth and that saliva must be involved in this processing. The aggregation or precipitation that caused astringency at $\mathrm{pH} 3.4$ and $\mathrm{pH} 2.0$ can be attributed to 2 different interaction mechanisms. Whey protein and salivary protein interact via electrostatic interactions at $\mathrm{pH}$ 3.4, whereas only salivary proteins undergo aggregation at $\mathrm{pH}$ 2.0. The precipitation of 
protein or other matter in the mouth without involving saliva will not lead to astringency; for example, the aggregation or precipitation of heated whey protein at $\mathrm{pH} 4.5$ to $\mathrm{pH} 5$ does not cause the perception of astringency.

It is noteworthy that intense astringency was displayed by lactoferrin solutions at $\mathrm{pH}<7$ (our unpublished data). However, no marked precipitation occurred in the mixtures of lactoferrin and saliva at any $\mathrm{pH}$. This may suggest that charge interactions between proteins and saliva may not be the only factors involved in the astringency of whey proteins at low $\mathrm{pH}$. At least, the intensity of astringency was not totally dependent on the amount of material precipitated.

\section{CONCLUSIONS}

The astringency of a whey protein beverage is related to the particle size and turbidity of the mixture of whey protein and human saliva. The intense astringency in the $\mathrm{pH}$ range from 3.0 to 4.0 was attributed to the large particle size and the high turbidity induced by electrostatic interactions between whey proteins and human salivary proteins in this $\mathrm{pH}$ range. At $\mathrm{pH}<3.0$, astringency may result from the precipitation of human saliva alone. Not all precipitation will cause astringency. The involvement of salivary proteins in the interaction is a vital factor for the perception of astringency in whey protein beverages.

\section{REFERENCES}

Bajec, M. R., and G. J. Pickering. 2008. Astringency: Mechanisms and perception. Crit. Rev. Food Sci. Nutr. 48:858-875.
Beecher, J. W., A. M. Drake, P. J. Luck, and E. A. Foegeding. 2008 Factors regulating astringency of whey protein beverages. J. Dairy Sci. 91:2553-2560.

Jöbstl, E., J. O'Connell, J. P. A. Fairclough, and M. P. Williamson 2004. Molecular model for astringency produced by polyphenol/ protein interactions. Biomacromolecules 5:942-949.

Joslyn, M. A., and J. I. Goldstein. 1964. Astringency principlesChanges in phenolic content in persimmons during ripening and processing. J. Agric. Food Chem. 12:511-515.

Kelly, M., B. Vardhanabhuti, P. Luck, M. A. Drake, J. Osborne, and E. A. Foegeding. 2010. Role of protein concentration and proteinsaliva interactions in the astringency of whey proteins at low $\mathrm{pH}$. J. Dairy Sci. 93:1900-1909.

Lawless, H. T., J. Horne, and P. Giasi. 1996. Astringency of organic acids is related to $\mathrm{pH}$. Chem. Senses 21:397-403.

Lee, C. A., and Z. M. Vickers. 2008. The astringency of whey protein beverages is caused by their acidity. Int. Dairy J. 18:1153-1156.

Lee, C. T., and H. T. Lawless. 1991. Time-course of astringent sensations. Chem. Senses 16:225-238.

Lymann, B., and B. G. Green. 1990. Oral astringency: Effects of repeated exposure and interactions with sweeteners. Chem. Senses 15:151-164.

Rykke, M., G. Smidstad, G. Roella, and J. Karlsen. 1995. Micelle-like structures in human saliva. Colloids Surfaces B 3:33-44.

Rykke, M., A. Young, G. Smidstad, G. Roella, and J. Karlsen. 1996. Zeta-potentials of human salivary micelle-like particles. Colloids Surfaces B 6:51-56.

Sano, H., T. Egashira, Y. Kinekawa, and N. Kitabatake. 2005. Astringency of bovine milk whey protein. J. Dairy Sci. 88:2312-2317.

Scharbert, S., M. Jezussek, and T. Hofmann. 2004. Evaluation of the taste contribution of theaflavins in black tea infusions using the taste activity concept. Eur. Food Res. Technol. 218:442-447.

Sowalsky, R. A., and A. Noble. 1998. Comparison of the effects of concentration, $\mathrm{pH}$ and anion species on astringency and sourness of organic acids. Chem. Senses 23:343-349.

Thomas, C. J. C., and H. T. Lawless. 1995. Astringent subqualities in acids. Chem. Senses 20:593-600.

Vardhanabhuti, B., M. A. Kelly, P. J. Luck, M. A. Drake, and E. A. Foegeding. 2010. Roles of charge interactions on astringency of whey proteins at low pH. J. Dairy Sci. 93:1890-1899. 